\title{
触 New Disease Reports \\ First report of a 16Srll phytoplasma associated with a witches' broom disease of Tamarix aphylla in Iran
}

\author{
S.A. Esmailzadeh Hosseini ${ }^{1} *$, M. Salehi ${ }^{2}$, G. Babaie ${ }^{3}$ and A. Paydar Ardakani ${ }^{4}$
}

${ }^{1}$ Plant Protection Research Department, Yazd Agricultural and Natural Resources Research and Education Center, AREEO, Yazd, Iran; ${ }^{2}$ Plant Protection Research Department, Fars Agricultural and Natural Resources Research and Education Center, AREEO, Zarghan, Iran; ${ }^{3}$ Plant Protection Research Department, Chaharmahal and Bakhtiari Agricultural and Natural Resources Research and Education Centre, AREEO, Shahrekord, Iran; ${ }^{4}$ Ardakan Natural Resources and Watershed Department, Yazd, Iran

*E-mail: saesmailzadeh@iripp.ir

Received: 02 Nov 2017. Published: 15 Dec 2017. Keywords: Tamarisk, Yazd

Tamarisk (Tamarix aphylla) has been used for windbreaks near agricultural crops and as shade trees in rural desert margins in Iran. Symptoms associated with tamarisk witches' broom (TWB) disease, including proliferation of shoots with short internodes and little leaf symptoms (Figs. 1-2) were observed in 34\% of trees surveyed in an area of 3500 ha in Chah Afzal (Yazd province, Iran) during 2014-15.

Nested polymerase chain reaction using the P1/P7 primers (Deng \& Hiruki, 1991; Schneider et al., 1995) followed by the R16mF2/R16mR2 and R16F2n/R16R2 primer pairs (Gundersen \& Lee, 1996) was carried out on DNA extracted from six diseased and three symptomless tamarisk plants. After 35 cycles, DNA fragments of c. 1.8, 1.4 and $1.25 \mathrm{~kb}$ respectively were obtained from each of the diseased tamarisk samples but not from symptomless samples. Restriction fragment length polymorphism (RFLP) analysis of R16F2n/R16R2 amplicons using AluI, HaeIII, HhaI, RsaI, MseI and TaqI restriction enzymes showed profiles identical to those of phytoplasmas belonging to the16SrII group. R16F2n/R16R2 sequences from six samples were identical to each other and a representative sequences was deposited in GenBank (Accession No. MF427724). BLAST analysis showed $99 \%$ nucleotide identity with other 16 SrII-D phytoplasmas including parsley witches' broom phytoplasma (KU501295), which is also found in Iran. Phylogenetic analysis using the neighbour-joining method (MEGA7) showed that the TWB phytoplasma clustered within the 16SrII group closest to papaya yellow crinkle (PYC) phytoplasma (Y10097) which is the type strain of the 16SrII-D group. Computer-simulated analysis with seventeen restriction endonucleases using $i$ PhyClassifier (Zhao et al., 2009) showed that the RFLP pattern derived from the TWB phytoplasma 16S rRNA gene was different from the reference patterns of all previously established 16SrII subgroups. The most similar was the RFLP pattern of PYC phytoplasma (Y10097) with a similarity coefficient of 0.97 .

This is the first report of a 16SrII phytoplasma associated with TWB disease in Iran and worldwide. TWB disease occurs near field crops heavily

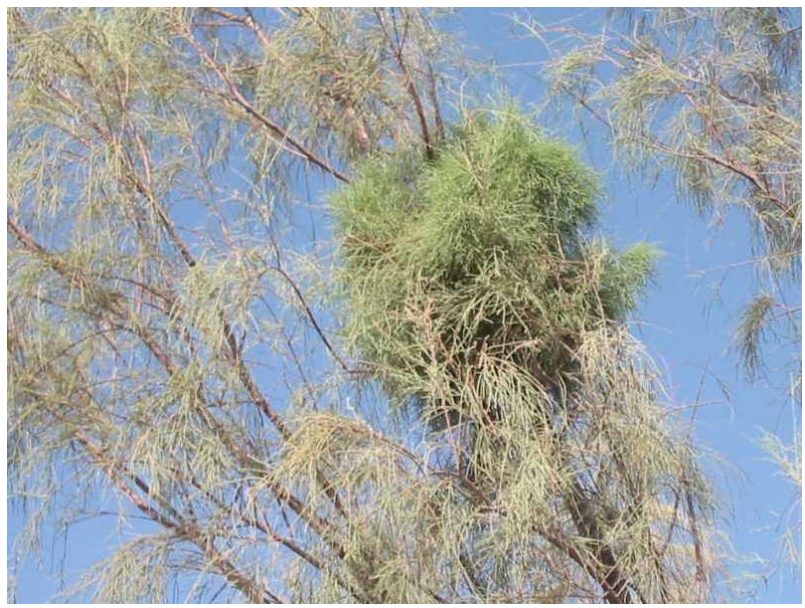

Figure 1

To cite this report: Esmailzadeh Hosseini SA, Salehi M, Babaie G, Paydar Ardakani A, 2017. First report of a 16Srll phytoplasma associated with a witches' broom disease of Tamarix aphylla in Iran. New Disease Reports 36, 22. http://dx doi. org/10.5197/j.2044-0588.2017.036.022 (c) 2017 The Authors infected with 16 SrII phytoplasmas such as alfalfa witches' broom (Esmailzadeh Hosseini et al., 2015) and sesame phyllody (Salehi et al., 2017) in Yazd and therefore tamarisk may have an important role in the epidemiology of the disease.

\section{References}

Deng S, Hiruki C, 1991. Amplification of 16S rRNA genes from culturable 53-61. http://dx.doi.org/10.1016/0167-7012(91)90007-D

Esmailzadeh Hosseini SA, Salehi M, Khodakaramian G, Mirchenari SM, in Iran. Phytopathogenic Mollicutes 5, 9-18. http://dx.doi.org/10.5958/2249-4677.2015.00057.2

Gundersen DE, Lee IM, 1996. Ultrasensitive detection of phytoplasmas by nested-PCR assays using two universal primer pairs. Phytopathologia Mediterranea 35, 144-151.

Salehi M, Esmailzadeh Hosseini SA, Salehi E, Bertaccini A. 2017. Genetic diversity and vector transmission of phytoplasmas associated with sesame phyllody in Iran. Folia Microbiologica 62, 99-109. http://dx.doi.org/10.1007/s12223-016-0476-5

Schneider B, Seemüller E, Smart CD, Kirkpatrick BC, 1995. Phylogenetic classification of plant pathogenic mycoplasma-like organisms or phytoplasmas. In: Razin S, Tully JG, eds. Molecular and Diagnostic Procedures in Mycoplasmology. New York, USA: Academic Press, 369-380. http://dx.doi.org/10.1016/B978-012583805-4/50040-6

Zhao Y, Wei W, Lee IM, Shao J, Suo X, Davis RE, 2009. Construction of an interactive online phytoplasma classification tool, $i$ PhyClassifier, and its application in analysis of the peach X-disease phytoplasma group (16SrIII). International Journal of Systematic and Evolutionary Microbiology 59, 2582-2593. http://dx.doi.org/10.1099/ijs.0.010249-0

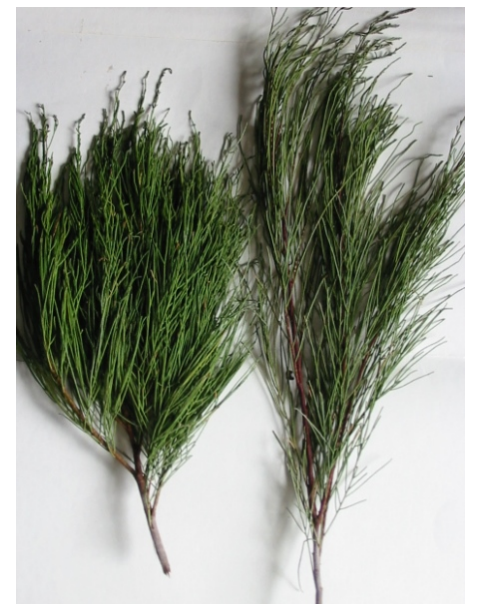

Figure 2 and nonculturable mollicutes. Journal of Microbiological Methods 14, Bertaccini A, 2015. An up to date status of alfalfa witches' broom disease 